RICHARD COLE

\title{
Esirism: The Impossibility of Ideological Neutrality in Snorra Edda
}

The story of how the Victorians and later the Nazis imposed their own ideology onto Old Norse mythology is relatively well known. Even the sternest soul must admit that there is something amusing about characters such as Laurence Waddell (b. 1854-d. 1938), a medic in the British Indian Army during the heyday of the British Empire, whose British Edda claims that the Poetic Edda 'is disclosed to be all unsuspectedly the great national epic of the ancient Britons of the pre-Christian period, which was sung down the ages by our ancestors in these islands.' One requires a rather darker sense of humour to be amused by Jan de Vries (b. 1890-d. 1964), a philologist whose works are still commonly cited in Old Norse studies, but who was to be found amongst the very few Dutchmen fleeing east to Germany when the Allies landed in the Netherlands in 1944. De Vries had become a member of the SS Ahnenerbe, his undeniable expertise in Nordic matters fused with an unhealthy fixation on 'Germanic' identity. ${ }^{2}$ We laugh at, or pity, characters such as Waddell and de Vries because their ideologically motivated engagement with Old Norse myth seems comically lacking in self-awareness. 'How could they not know that it was only their ideologies which had made them interpret Old Norse in such distorted ways?' we might sigh through our smirking.

But in our laughter, and if we use verbs such as 'abuse' to describe what right-wingers have often done to Old Norse, we tacitly position Old Norse myth as somehow ideologically neutral. The purpose of this study is to fortify the viewpoint that, in the discrete body of Old Norse myth presented

1 Waddell, British Edda, p. viii.

2 Hofstee, 'The Essence of Concrete Individuality', pp. 548-50; Junginger, 'Introduction', pp. 74-81; Lincoln, 'Rewriting the German War God', pp. 192-93.

Richard Cole is an assistant professor of Medieval European History at Aarhus Universitet. He was awarded his PhD in Old Germanic Languages and Literatures from Harvard University in 2015. He has held positions at Harvard, the University of Notre Dame, and UCL - the latter being where he began his career in Scandinavian Studies.

Old Norse Myths as Political Ideologies: Critical Studies in the Appropriation of Medieval Narratives, ed. by Nicolas Meylan and Lukas Rösli, AS 9, pp. 27-46

() BREPOLS PUBLISHERS 
by Snorri Sturluson (d. 1242), ${ }^{3}$ there is a coherent ideology governing the actions of the gods. That ideology will be shown to have affinities with late ideologies, such as the unlikely pairing of anarchism and colonialism, though it must be stressed that it is really a sui generis phenomenon, one which we might call 'Æsirism. 'The value of comparisons with these modern '-isms' will be in illuminating the key policy concerns of the gods, and illustrating the timelessness of certain ideas. There will be no suggestion that Old Norse myth contained ideological elements of which modern ideologies are direct descendants, as per Christen Jonassen's claims. ${ }^{4}$

\section{Is Asirism Republican, Monarchist - or Anarchist?}

Beginning with the political organization of the Æsir, it ought to be noted that in the Edda Snorri mostly shies away from referring to Óðinn as a king, or as a holder of any other feudal rank. There are some qualifications to be made here. The mysterious sword-juggler who greets Gylfi at Ásgarðr does briefly describe Óðinn (or the trinity of Hár, Jafnhárm and Priði, which he hides behind) as a king:

Gylfi sá mann í hallar durunum ok lék at handsǫum ok hafoi sjau senn á lopti. Sá spurði hann fyrr at nafni. Hann nefndisk Gangleri ok kominn af refilstigum ok beiddisk at sœkja til náttstaðar ok spurði hverr hǫllina ætti. Hann svarar at pat var konungr peira. 'En fylgja má ek pér at sjá hann. Skaltu pá sjálfr spyrja hann nafns'.

(Gylfi saw a man at the door of the hall, and he was playing with short-swords and had seven in the air at once. He asked him at once

3 It must be underlined that I will not treat Old Norse mythology as a total system, and will notead conve not convinced by Snorris authorship of the Edda are invited to substitute mentally the name 'Snorri' for anonymous author.' I trust it will be found that none of my arguments will be meaningfully affected. On Snorri's authorship, sce: Wanner, Snorri Sturluson and the 'Edda', pp. 26-29; Clunies Ross, A History, pp. 161-63.

4 Jonassen, 'Some Historical and Theoretical Bases of Racism.

5 Snorri, Gylfaginning, pp. 7-8; Codex Regius 1"; Codex Trajectinus 2v. To reassure readers who might be concerned that I am using a critical edition to cherry-pick from different recensions of the Snorra Edda, I also cite the manuscript tradition, which is consistently reflected in Faulkes's edition. For my belief in the validity of a critical edition of the text, see: Cole, 'Philology', esp. pp. 518-2s. The Uppsala tradition, recently edited by Heimir Pálsson, is fascinating but I agree with Faulkes that it ought to remain an outlier - especially given ts fascinating but agree with Fally given (n) tracts from Snorri's figurative 'desk, while Regius/Trajectinus represents Snorri's polished version, is enticing: Faulkes, 'Introduction', xxx-xxxii. Cf. Heimir Pálsson, 'Introduction', xlii-xliii, cxvi-cxix. for his name. He [Gylfi] called himself Gangleri, arrived from secret paths, and asked that he might seek a place to stay for the night, and inquired who owned the hall. He [the juggler] replies that it was their king. 'I should take you to see him. Then you can ask him his name for yourself'. $)^{6}$

However, we ought not to ascribe too much truth to the jester's words. The purpose of this scene is to foreshadow the series of disorienting deceptions and half-truths, which will eventually beguile Gylf into worshipping the Æsir. Even the hall into which Gylfi enters is an illusion. It seems more likely that the jester is describing Óðinn as a konungr in an effort to explain the Æsir in terms that Gylfi, himself a king, will understand. Snorri himself deploys this kind of allegory when he suggests an affinity between King Priam of Troy and Óðinn of Ásgarðr. Firstly in the prologue: ${ }^{7}$

Nær miðri verọldunni var gọrt bat hús ok herbergi er ágætast hefir verit, er kallat var Troja. Pat kolllum vér Tyrkland. Pessi staðr var myklu meiri gòrr en aðrir ok með meira hagleik á marga lund með kostnaði ok f̨ngum er par váru til. Par váru tólf konungdómar ok einn yfirkonungr ok lágu mǫrg pjóðlǫnd til hvers konungdóms. Par váru í borginni tólf hoqfuðtungur. Pessir hǫð̊ingjar hafa verit um fram aðra menn pá er verit hafa í verǫldu um alla manndómliga hluti. ${ }^{8}$

(Near the centre of the world a house and settlement was made which is the most wonderful there has ever been, which was called Troy. We call it Turkey. This place was built much larger than others and with more craftsmanship in many ways with whatever material and treasures that were at hand. There were twelve kingdoms there and one high king, and many nations were subject to each kingdom. There were in that city twelve central chieftains. These chieftains were further ahead than any other people who have ever been in the world when it comes to all brave deeds.)

And secondly in Skáldskaparmál, when Snorri offers a typological parallel between Óðinn being devoured by the Fenrisúlfr and Priam being killed by Pirrus, son of Achilles. (Incidentally, the parallel cannot be considered entirely convincing, because by Snorri's own account Fenrir is spared because he is in a place of sanctuary - Fenrir is not the one doing the violating of a

6 All translations are my own unless otherwise stated.

7 On the unity of the Prologue with the rest of Snorri's writing, see: Clunies Ross, 'Royal Ideology', pp. 25-29.

8 Snorri, Gylfaginning, p. 4; Codex Trajectinus Ir. 
sanctuary, as Pirrus is in the Aeneid. Oddly, Virgil even implies that Priam is at fault for having his own blood spilled at the altar):9

Priamus konungr í Troju var hǫfðingi mikill yfir ǫllum her Tyrkja ok hans synir váru tignastir af ǫllum her hans ... En Pirrus, honum jǫfnuðu peir til Fenrisúlfs, hann drap Óðin, en Pirrus mátti vargr heita at peira trú pvíat eigi pyrmði hann griðastǫðunum er hann drap konunginn í hofinu fyrir stalla Pórs. ${ }^{10}$

(King Priam in Troy was a great chieftain over the entire army of the Turks and his sons were the noblest of all his army ... And they [the Æsir] compared Pirrus to the wolf Fenrir, who killed Óðinn, and Pirrus could be called a wolf in their thought because he did not honour places of sanctuary when he killed the king in the temple in front of Pórr's altar.)

These glancing allusions to Óðinn as a king are essentially periphrastic. When the jester describes Óðinn as his king or when Snorri implies that Óðinn might be a dim remembering of King Priam, the message is not so much that Óðinn was a king, but rather that he was somewhat like a king. Both the jester and Snorri are addressing audiences for whom kingship was the mode of governance in most of the world (Snorri addressing thirteenth-century Old Norse-speakers, the sword-juggler addressing the legendary King Gylfi). Similarly problematic is the moment when one of Óđinn's aliases, Hár, is once described as a konungr, but only in the narrative frame when the Æsir are being extremely deceptive about themselves." Finally, in one solitary point in Ynglinga saga, Snorri refers to Óðinn as 'draugadróttinn eða hangadróttinn"12 (the Lord of the Undead or the Lord of the Hanged). ${ }^{13}$ In Snorra Edda, there is no equivalent to draugadróttinn, while hangadróttinn has become hangagoo (God of the Hanged), as though Snorri is retreating from even the slightest suggestion that Óðinn could hold a rank equivalent to those of a feuda court. ${ }^{14}$ Thus, it still remains true that in the Edda the term konungr (king) or even dróttinn (lord) is never used of Óðinn when 1) Snorri is speaking in

9 'Instat vi patria Pyrrhus ... vidi ipse furentum caede Neoptolemum geminosque in limin Atridas, vidi Hecubam centumque nurus Priamumque per aras sanguine foedantem quos ipse sacraverat ignis'. (Pyrrhus, urged on with the force of his father ... I myself saw Neoptolemus [i.e. Pyrrhus] and both the sons of Atreus in the doorway, furious in slaughter I saw Hecuba and her hundred daughters, and Priam between the altars, desecrating with blood the fires he had sanctified himself). Virgil, Acneid, pp. 348-50.

10 Snorri, Skáldskaparmál, pp. 5-6; Codex Regius 20; ; Codex Trajectinus 20 lacks mikill but is otherwise identical.

Snorri, Gylfaginning, p. 8; Codex Regius $1^{\text {v }}$; Codex Trajectinus 2 .

12 When quoting from the Edda, I use single quotation marks for when Snorri's own narrative voice is speaking, and double quotation marks for Ódinn/Hár or Gylf/Gangleri.

3 Snorri, Ynglinga saga, p. 18

14 Snorri, Gylfaginning, p. 21; Codex Regius $6^{r}$; Codex Trajectinus $6^{2}$. his own narrative voice, or 2) when Oðinn is telling stories about himself, rather than an alias.

When considered alongside other bodies of mythology, this is somewhat unusual. In Greco-Roman myth, Zeus is not infrequently the $\beta a \sigma i \lambda \varepsilon v$ co $^{\alpha} v \alpha$ (king) of the other deities, e.g. Hesiod Z $\varepsilon v \varsigma \delta \varepsilon \theta \varepsilon \omega \nu \beta a \sigma i \lambda \varepsilon v \varsigma$ (Zeus, king of the gods), cf. Homer $\Delta u$ Koovı $\omega v \iota$ a $v \alpha \kappa \tau$ (King Zeus, son of Cronos), etc. ${ }^{15}$ The situation with regard to Roman sources is more complex, but there too the epithet Jupiter rex appears to have had some degree of currency. ${ }^{16} \mathrm{~A}$ similar sense of celestial hierarchy is discernible in Hebrew and Canaanite myth, hence אדני (Lord), בעל (master) and deity names like Malku (king). In the Edda, however, Snorri's chief deity is never straightforwardly a konungr or a dróttinn - not even when he is ruling over geographical territories in Northern Europe. Óðinn was apparently 'tignat um alla konunga' (honoured above all kings) ${ }^{17} \mathrm{He}$ was the "œztr eða elztr allra goða" (highest or oldest of all the gods).$^{18}$ Nonetheless, the closest thing to a rank that Snorri's narrative voice uses to describe Óðinn, either in his Edda or in Ynglinga saga, is the word hoffingi (head, chief). Given that Snorri was writing at a time when the Christian God was referred to in Snorri's own language as dróttinn várr (Our Lord) or 'konungr allra konunga' (king of all kings), why not use a pinch of the contemporary language of power to illustrate his own fictional world? ${ }^{19}$

One might suppose that the reason for this curious lack is that Snorr otherwise did not consider the rank of king to be used by Old Norse speakers until the reign of the legendary King Dyggvi, as Sverre Bagge has pointed out. ${ }^{20}$ In Ynglinga saga, Snorri writes that: 'Dyggvi var fyrst konungr kallaðr sinna ættmanna, en áor váru peir dróttnar kallaðir, en konur peira dróttningar, en drótt hirðsveitin' (Dyggvi was the first to be called king of his lineage, and before they were called lords, and their wives were called queens, and thei lords were called 'the retainers'). ${ }^{21}$ However, this explanation is not tenable, as Snorri also carefully avoids referring to Óðinn as a dróttinn in his Edda when it would otherwise be a quite convenient appellation (Óðinn having supposedly ruled Sweden seven generations prior to Dyggvi). A simpler solution is that Snorri imagines that the Æsir did not have a monarchy, nor any sort of comparable institution. Indeed, this explanation is strongly suggested by the further details he provides about the government of the Æsir in Sweden

Par pótti Óðni fagrir lands kostir ok kaus sér par borgstað er nú heita Sigtúnir. Skipaði hann par hǫfðingjum ok í pá líking sem verit hafði í

15 Hesiod, Theogony, p. 74; Homer, Iliad, p. 294

16 Fisher, The 'Annals' of Quintus Ennius, pp. $45-48$.

17 Snorri, Gylfaginning, p. 5; Codex Regius ${ }^{r}$; Codex Trajectinus Iv

18 Snorri, Gylfaginning, p. 8; Codex Regius 2ri Codex Trajectinus 2v.

19 Old Norwegian Homily Book, ed. by Indreb $\bullet$, p. 33.

20 Bagge, Society and Politics, pp. 192-94, 296.

21 Snorri, Ynglinga saga, p. 34 
Troja, setti tólf họfuðmenn í staðinum at dœma landslog, ok svá skipaði hann réttum ǫllum sem fyrr hǫðu verit í Troju ok Tyrkir váru vanir. ${ }^{22}$

(It seemed to Óðinn that there were beautiful qualities to that country, and he chose for himself a city there which is now called Sigtuna. ${ }^{23}$ $\mathrm{He}$ also arranged chieftains there in the likeness of what had been in Troy, putting twelve chief men in the city to judge the laws of the land, and he arranged all the laws as they had been in Troy, and as the

Turks were accustomed.)

Later in the Edda, Óðinn, in the guise of Hár, furnishes us with his own account about how the Æsir established their system of government:

Hár mælir: "Í upphafi setti hann stjórnarmenn ok beiddi bá at dœma með sér ørlog manna ok ráða um skipun borgarinnar. Pat var par sem heitir Iðavǫllr í miðri borginni. Var pat hit fyrsta peira verk at gera hof pat er sæti peira standa í, tólf ǫnur en hásætit pat er Alfǫðr á. Pat hús er bezt gert á jǫrðu ok mest. Allt er pat útan ok innan svá sem gull eitt. Í peim stað kalla menn Glaðsheim. Annan sal gerðu peir, pat var hǫrgr er gyðjurnar áttu, ok var hann allfagr. Pat hús kalla menn Vingólf ... Par næst settusk guðin upp í sæti sín ok réttu dóma sína ok mintusk hvaðan dvergar hơðu kviknat í moldunni ok niðri i jǫrðunni svá sem maðkar í holdi. ${ }^{24}$

(Hár says: "In the beginning he [Óðinn] established potentates and ordered them to judge amongst themselves the fates of men, and decide about the arrangement of the city [i.e. Ásgarðr]. It was there, in the middle of the city, that there was the place called Iðavolllr. It was their first task to make the temples in which their seats would stand, twelve other than the high-seat which the All-Father [Óðinn] owns. That house is the best made and the biggest on earth. All over the outside and the inside it is as though it is gold. In that place is where men call Glaðsheim. They made another hall, which was the sanctuary that the goddesses owned, and it was extremely beautiful. Men call that house Vingólf ... Next the gods sat up in their seats and legislated their courts, and recalled [alt. discussed] how the dwarves had been brought to life in the dirt and down in the earth, like maggots in flesh.")

22 Snorri, Gylfaginning, p. 6; Codex Regius $1^{r}$; Codex Trajectinus $2^{r}$ though with Sigtún rather than Sigtúnir.

23 In Ynglinga sagu it is not Sigtun in Sweden but Odense in Denmark that Óðinn chooses for his capital (p. 14). It is curious that Snorri at no point locates the mythic metropolis in Norway, given that he travelled there and attempted to win the favour of both King Hákon Hákonarson and the pretender Jarl Skúli (d. 1240).

24 Snorri, Gylfaginning, p. 15; Codex Regius $4^{r}$; largely identical with Codex Trajectinus $4^{v}-5^{r}$
Although the Edda is innovative in its frequent comparisons between Asgarð and Troy, Snorri expounds a similar model of Æsirist government in his Ynglinga saga, omitting Troy but maintaining the principle that the Æsir's constitution was brought with them from the East:

Fyrir austan Tanakvísl i Ásía var kallat Ásaland eða Ásaheimr, en hơfuðborgin er var í landinu, kolluðu beir Ásgarð. En í borginni var hơðingi sá, er Óðinn var kallaðr. Par var blótstaðr mikill. Pat var par siðr, at tólf hofgoðar váru œztir. Skyldu peir ráða fyrir blótum ok dómum manna í milli. Pa eru díar kallaðir eða dróttnar; beim skyldi bjónostu veita ok lotning alt fólk ... En Óðin ok pá höfðingja tólf blótuðu menn, ok kölluðu goð sín ok trúðu á lengi síðan. ${ }^{25}$

(To the East of the river Don in Asia was called Ásaland [Land of the Æsir] or Ásaheimr [World of the Æsir], and they called their capital city which was in the country Ásgarðr. And in the city there was a certain chieftain who was called Óðinn. There was a great place of sacrifice there. It was a tradition there that twelve temple-chiefs were the highest. They would preside over sacrifices and arbitrate in the courts of men. They are called diar or 'Lords'. All the people were supposed to give them service and pay them reverence ... And long ago people made sacrifices to Óðinn and those twelve chieftains, and called them their gods and believed in them.

The Skáldskaparmál section of the Edda suggest that after these thirteen, eigh further positions were reserved for the goddesses. ${ }^{26}$ Across the Snorronic corpus, there is a clear commitment to the notion that the Æsir had been governed by a council of twelve (twenty including the goddesses), in addition to Óðinn himself. Except in the case of the prologue, the language used to describe these potentates is that of judges rather than royalty or appointed officials, e.g. at dóma 'to judge' and the nouns dómr 'court' and landslog 'law of the land'. This is in the spirit of the Eddic poetry from which Snorri was working, where it is implied that the gods meet in council to discuss important matters, rather than having a strict 'top-down' system of organization. Consider for example, the refrain of the prophetic poem Voluspá: 'Pá gengu regin oll / á rǫkstóla, / ginnheilogg goð, / ok um pat gættusk' (The powers all went / to the thrones of fate / the divine gods / and this they discussed). ${ }^{27}$ This apparent kritarchy also faintly recalls the time when the Israelites reject kings in favou of magistrates, e.g. Judges 2:18: 'And when the Lord raised them up judges, then the Lord was with the judge, and delivered them out of the hand of their enemies all the days of the judge: for it repented the Lord because of their

25 Snorri, Ynglinga saga, pp. 11, 20.

26 Snorri, Skáldskaparmál, 1; Codex Regius 18 $8^{r}$; Codex Trajectinus 18.

27 Poetic Edda, ed. by Neckel and Kuhn, pp. $2,6$. 
groanings by reason of them that oppressed them and vexed them'. However, the most obvious analogue to the Æsir's preference for judges rather than kings must be the Icelandic Commonwealth. As Bjarni Aðalbjarnarson noted concerning the system of twelve judges in Ynglinga saga: 'Petta minnir á störf íslenzkra goða í heiðnum tỉ’' (This reminds one of the work of the Icelandic chieftains in the age of paganism).$^{28}$

It would, however, do a grave disservice to Snorri if one were to suggest that he simply took the Icelandic system of governance and projected it onto the Æsir. Firstly, Snorri was no ardent republican, even if the Æsir apparently are. According to Íslendinga saga, Snorri was even given a feudal rank by King Hákon Hákonarson (r. 1204-1263), and charged with convincing the Icelanders to accept Norwegian royal rule. ${ }^{29}$ Secondly, the constitutional powers of the Æsir far outstrip those of medieval Icelandic lawmen. The councillors of the medieval Icelandic Alpingi, who were known as godar, collectively made rulings on given cases brought to them for arbitration. They also emended the law through the appointment of judges. But as there was no executive in medieval Iceland, they could not rule on policy. For example, they could not revalue their currency or take Iceland to war - Iceland had neither mints nor a means of raising a national army. The Æsir, on the other hand, commission earthworks, build cities, and grapple with serious policy problems regarding how threats to their dominion are to be handled.

In a sense, Æsirist government is a utopian realization of the Icelandic Commonwealth. However, when all the flaws of the Icelandic situation are removed, Æsirism stands apart as a unique system in its own right. The Æsir seem to operate on the same basic principles as the Icelandic godar. They have no king, and it does not ever seem to occur to them that they should. They identify as judges, that is to say as impartial deliberators rather than republican despots. But unlike the Icelanders, 1) they possess an urbanized civilization, and 2) they have a streamlined council of twelve, with Óðinn in a primus inter pares position, while the Icelandic Alpingi had thirty-nine delegates, who were frequently to be found engaged in bloodthirsty feuds.

From a transhistorical perspective, the most descriptive label one could apply to the Æsirist approach to decision making is a form of anarchism. Here, the comparison with medieval Iceland is again germane. A cynic might comment that little scholarly fruit has been harvested relative to the amount

28 Bjarni Adalbjarnarson, notes to Snorri Sturluson, Heimskringla l, 11 n. 42. There were Icelandic Commonwealth, so the comparison is also valid between the Æsir and how the Commonwealth worked during Snorri's own time.

29 Sturla bórðarson, Sturlunga saga [Íslendinga saga], I, 340: 'En peir Hakon konungr ok Skvli iarl gerpv Snorra lenðan mann sinn; var pat mest rad peira iarls ok Snorra. Enn Snorri skylldi leita við Islendinga, at peir sneriz til lydni við Noregs havfðingja'. The title is issued in the name of the young king, although Sturla underlines that this was really an agreement between Skúli and Snorri. of energy expended in the intellectual skirmish between Anarcho-Capitalists and Anarcho-Socialists over who has a better claim to the medieval Icelandic commonwealth..$^{30}$ But at least one can say that both sides proceed from a reasonable point: it is true that for three centuries Icelanders strove to avoid kings and civil servants of any kind. De facto, local potentates exercised a tremendous amount of power over their compatriots. Indeed, the graphic violence of the Íslendinga- and Sturlunga sögur strongly indicates that everyday life for many Icelanders was violent and exploitative. Nonetheless, the studious avoidance of formalized executive power suggests an intense ideological commitment on the part of many Icelanders. This commitment should be broadly characterized as anarchist. ${ }^{31}$ It had personal liberty for its denizens at its theoretical core, ${ }^{32}$ and aimed to make decisions through courts and consensus (even if in practice thuggery and nepotism prevailed). Æsirism appears to have just the same aims, and so the Æsir attitude to domestic governance should similarly be conceived of as a species of anarchism.

It is important to stress, however, that Æsirism as a whole is manifestly not a species of anarchism, even if its views on specific matters are best described that way. The Æsir may believe that none of their tribe should hold official rank over another. They may be committed to government by consensus between the gods. But they in no way reject the option of exercising power over other, non-Æsir peoples. In fact, they are heavily invested in the use of violence in order to exploit and control their neighbours. As shall be seen, Æsirism may look like anarchism at home, but it looks much like colonialism abroad.

\section{Building Walls, and Other Colonial Projects}

One of the key concerns of the Æsir is their difficult relationship with the peoples that surround them, the giants. Snorri uses various terms to describe these giants (jotnar). Some of these are probably intended to denote separate sub-types, not all of them being tall in the way that we think of giants today (e.g jotunn, the catch-all term for a 'giant', gýgr, 'giantess', rísi, probably implying a tall giant, hrímpurs 'ice giant', bergrísi 'mountain giant', leirjotunn 'clay giant', somewhat golem-like; still further terms are found in the Poetic Edda). The relationship between the Æsir and the giants is more complex than simply being adversarial, although admittedly its combative dimension is the most

30 For the socialist-anarchist claim, see: Kropotkin, Mutual Aid, pp. 157-61; AFAQWorking Group, 'Medieval Iceland' (n. d., n. p). On the anarcho-capitalist claim, see: Friedman, 'Private Creation; Friedman, Machinery of Freedom, pp. 202-08; Friedman, Law's Order, pp. 263-78. As a corollary, see: Wax and Wax, 'The Vikings', pp. 1-10.

31 Pencak, The Conflict of Law and Justice, pp. 1-4.

32 As in any polity, who gets to be a denizen is an awkward topic: slaves, outlaws, nonheterosexuals, in some regards women, etc., are just some of the groups who were either on the edge of society or excluded from it altogether from the outset. 
prominent strain. A good example of the differing strands in Æsir-jotna relations is the myth of the Master Builder. In the following scene, the Æsi decide to build a fortification to keep the giants out, and they have no intention of paying for it themselves:

Pat var snimma í ǫndverða bygð goðanna, pá er goðin hǫfu sett Miðgarð ok gert Valhǫll, pá kom smiðr nokkvorr ok bauð at gera peim borg á prim misserum svá góða at trú ok ørugg væri fyrir bergrisum ok hrímpursum pótt peir komi inn um Miðgarð. En hann mælir sér pat til kaups at hann skyld eignask Freyju, ok hafa vildi hann sól ok mána. Pá gengu Æsirnir á tal ok réðu ráðum sínum, ok var bat kaup gert við smiðinn at hann skyldi eignask pat er hann mælir til ef hann fengi gert borginni á einum vetri, en hinn fyrsta sumars dag ef nokkvorr hlutr væri ógjorr at borginni pá skyldi hann af kaupinu ... En er á leið vetrinn, pá sóttisk mjok borgargerðin ok var hon svá há ok sterk at eigi mátti á pat leita. En pá er prír dagar váru til sumars pá var komit mjǫk at borghliði. Pá settusk guðin á dómstóla sína ok leituðu ráða ok spurði hverr annann hverr pví hefði ráðit at gipta Freyju í Jǫtunheimum eða spilla loptinu ok himninum svá at taka paðan sól ok tungl ok gefa jǫtnum. ${ }^{33}$

(It was early in the first days of the settlement of the gods, when the gods had established Miðgarðr and built Valhọll, that a certain craftsman came and offered to build for them inside of three seasons a fortress so good that it would be reliable and safe against the Mountain Giants and the Ice Giants, even if they got into Miðgarðr. And he named his price as being that he would marry Freyja, and he also wanted to have the sun and the moon. Then the Æsir had a discussion and reached their decision, and the deal was made with the craftsman that he should have what he had named if he could get the fortress built inside of one winter, and at the first day of summer if any part of the fortress was incomplete then he would forfeit his payment ... But as winter wore on, the construction of the fortress went very well, and it was so tall and strong that one could not attack it. And when there were three days until summer it was very nearly up to the fortress gates. Then the gods went to their thrones of judgement and held council, and asked each other who it was who had advised marrying Freyja off to the Giantlands or ruining the sky and the heavens by taking away the sun and the moon and giving it to the giants.)

This episode betrays two principal ideological commitments: 1) That the giants should be kept segregated from the Æsir, preferably by fortifications, ${ }^{34}$

33 Snorri, Gylfaginning, p. 34.

34 As Lukas Rösli has pointed out to me, it is striking that it is a giant who first offers to build the wall. The Æsir are excited by the idea, but the wall was a pre-existing project which was out for tender. One might read into this the tendency for a small portion of a disadvantage
2) that giant men must on no account have access to Æsir women ${ }^{35}$ - even if that sexual access was the agreed upon price for a 'legitimate' transaction (I use scare quotes because the notion of a transaction is itself ideologically conditioned - the minute someone tells you that what they are proffering is not ideology but is instead common sense you can be quite sure you are about to be confronted with a highly ideological gesture). ${ }^{36}$ Why is it that the giants must be kept out? There is a tendency to frame this desire on the part of the Æsir as a defensive measure, as though it were purely reactive. Thus Gabriel Turville-Petre: '[Dórr] maintained the order of the universe, defending our world ... and the world of gods ... he held the forces of chaos in check.37 Or Hilda Ellis Davidson: '[Pórr's hammer] was not only the symbol of the destructive power of the storm, and of fire from heaven, but also a protection against the forces of evil and violence. Without it Asgard could no longer be guarded against the giants. ${ }^{38}$

There is no error here on the part of scholars. Medieval commentators too tended to frame the Isir's actions towards the giants as defence, not offence. Snorri himself cites a verse by Úlfr Uggason (fl. 980s) which describes the god Heimdallr as the 'frægr ragnarein-vári' (the famous rainbow-defender), ${ }^{39}$ or in Clunies Ross's alternate parsing of the verse the 'frægr rein-vári ragna' (the famous ground-defender of the gods) ${ }^{40}$ Snorri also cites a verse by Pjóðólfr of Hvínir (fl. early 90os) which describes Pórr and the other more martial Æsir as the 'varnendr goða' (defenders of the gods). ${ }^{41}$ The description of the Æsir defending themselves against the giants is perfectly fair and accurate, but it obscures the reality that not all instances of self-defence are ethically equal. If one approaches a stranger in a public house, throws a punch at him/ her, and then shields oneself against the ensuing blows one receives in return, it is wholly true to say that one is defending oneself. Yet saying that would obviously not be a complete account of events.

Similarly, while it is true to say that the Æsir are protecting themselves against the giants, verses such as those of Úlfr and bjóðólfr neglect to mention how the conflict between Æsir and giants began. Snorri alone depicts the very beginnings of the animosity. The detail that the primordial humanoid was a giant named Ymir, and that various cosmological fixtures (the earth, the sky, the clouds, etc.) were made from his body is known from Eddic poetry, e.g. Vafprúðnismál stanza 21: 'Ór Ymis holdi var iǫrð um scepuð, / enn ór beinom

group to collaborate with an oppressive power in order to pursue individual gain, but this is a topic for another time.

35 Clunies Ross, Prolonged Echoes, , esp. pp. 107-27.

36 Žižek, Sublime Object, pp. 48-50; Žižek, First as Tragedy, pp. 9-28.

37 Turville-Petre, Myth and Religion, p. 75 .

38 Ellis Davison, Gods and Myths, p. 84

39 Snorri, Skáldskaparmál, p. 20; Codex Regius 22 ${ }^{\mathrm{v}}$; Codex Trajectinus 23

40 Clunies Ross, Poctry and Poctics, p. 58.

41 Snorri, Skáldskaparmál, p. 31; Codex Regius 25r; Codex Trajectinus 26r 
biorg, / himinn ór hausi ins hrímkalda iotuns, / enn ór sveita siór' (From the flesh of Ymir the earth was made / and from the bones mountains / the sky from the skull of the ice-cold giant / and from the blood the seas) ${ }^{42}$ But Snorri provides the further detail that it was a direct ancestor of the Æsir who murdered the progenitor of the giants. In Snorra Edda, Óðinn admits that: "Synir Bors drápu Ymi jọtun. En er hann fell, pá hljóp svá mikit blóð ór sárum hans at með pví drektu beir allri ætt hrímbursa, nema einn komsk undan með sínu hýski" (The sons of Borr killed Ymir the giant. And when he fell so much blood ran out his wounds that all of the race of the Ice-Giants drowned, except one who escaped with his family). ${ }^{43}$ Borr was the father of Óðinn, and the son of Búri, the second anthropoid who emerged independently of Ymir, therefore the 'sons of Borr' most likely includes Óðinn himself. Óðinn attempts to justify this act of violence by telling Gylf that "Fyr øngan mun játum vér hann guð. Hann var illr ok allir hans ættmenn" (In no way can we call him [Ymir] a god. He was evil, as are all his descendants). ${ }^{44}$ However, coming from Oðinn, the leader of the Æsir and probably the man who threw the fatal blow, the explanation is really little more convincing than calling Ymir a 'bad hombre.' What Ymir did to deserve his fate is not mentioned by Snorri. It has been suggested that there may be an Indo-European myth here concerning the 'murder [of] a senior male kinsman on the mother's side'ts It may well also be that Ymir, as ' $[t]$ he first anthropomorphic giant, having been created from noxious matter, was a flawed one, a giant ... [the giants'] domain was an "other world" which incorporated forces threatening to the Æsir'. ${ }^{6}$ But these are scholarly inferences on the background of comparative mythological readings. In Snorri's literary work, the reader remains at liberty to reject Oðinn's anti-giantish bluster and press the question that Gylfi does not: 'what did Ymir do wrong?'

Snorri continues to expound a history of Æsir-giant relations founded on exclusion and appropriation. Having used Ymir's blood to make the sea, his flesh to make the earth, his skull to make the sky and his brains to make the clouds, the Æsir have one last gruesome and mocking use for his corpse. Óðinn explains that:

"Hon [jogrðin] er kringlótt útan, ok par útan um liggr hinn djúpi sjár, ok með peiri sjávar strǫndu gáfu peir lǫnd til bygðar jętna ættum. En fyrir innan á jǫrðunni gerðu peir borg umhverfis heim fyrir ófriði jotna, en til peirar borgar hǫfu peir brár Ymis jǫtuns, ok kolluðu pá borg Miðgarð."47

42 Poetic Edda, ed. by Neckel and Kuhn, p. 48.

43 Snorri, Gylfaginning, p. 11; Codex Regius $3^{r}$; Codex Trajectinus $3^{v}$.

44 Snorri, Gylfaginning, p. 10; Codex Regius 2 ${ }^{v}$; Codex Trajectinus $3^{v}$.

45 Clunies Ross, Prolonged Echoes, 1, 158, see also p. 198.

46 Clunies Ross, Prolonged Echocs, I, 185.

47 Snorri, Gylfaginning, p. 12; Codex Regius $3^{r}$; Codex Trajectinus $4^{r}$
("It [the earth] is circular on the outside, on the outside lies the deep ocean, and by the shore of that ocean they [the Æsir] gave land for the settlement of the race of giants. But further inwards on the earth they made a fortification all around the world against the warlikeness of the giants, and for those fortifications they used the eyelashes of Ymir the giant, and they called the fortification Miðgarðr.")

The story that Snorri tells - which our other sources do not - is that the Æsir stole the future from the giants. ${ }^{48}$ Listening uncritically to Óðinn's words or reading only the Poetic Edda, one might get the impression that the giants are innately covetous and destructive. The walls that the Æsir erect, both in the passage cited above and in the myth of the master builder cited previously, would then be straightforward responses to an implacable threat. Snorra Edda reveals that the history is not so simple: In fact, 1 ) the giants predate the Æsir, 2) the giants' patriarch was killed by Óðinn, apparently on very suspect grounds, 3) the Æsir were then relegated to the fringes of the world, kept out by palisades fashioned from their progenitor's slain body. On this third point, it is worth noting that Óðinn is keen to play down the inclemency of the giants' remaining territories. Like an Apartheid minister defending the policy of confining indigenous people to unviable Bantustans, he says merely that the giants live on lands by the coast. ${ }^{49}$ However, the places where giants appear to live elsewhere in Snorra Edda are very much inhospitable areas. There appear to be giants living in the area of the universe known as Muspell which is unbearably hot:

Fyrst var bó sá heimr í suðrhálfu er Muspell heitir. Hann er ljóss ok heitr. Sú átt er logandi ok brennandi, er hann ok ófœrr fleim er par eru útlendir ok eigi eigu par óðul. Sá er Surtr nefndr er par sitr á lands enda til landvarnar. Hann hefir loganda sverð, ok í enda veraldar mun hann fara ok herja ok sigra oll goðin ok brenna allan heim með eldi..$^{\text {so }}$

(The first world was in the southern region and is called Muspell. It is bright and hot. This part is on fire and burning, and it is impassible

48 Clunies Ross discusses the myth as a totalized system rather than Snorra Edda exclusively, as we do here. Although she focuses on erotic elements, her phrase ' $t$ t $]$ he gods' designs upon the giant world' pre-empt my own giantish sympathies: Clunies Ross, Prolonged Echoes, $\mathrm{I}_{\mathrm{H}}$ 127.

49 I admit that this is a highly emotive example. It is worth stressing that the Giantlands, like the Bantustans, are carved out of whatever territory is left over once those in control have allotted for themselves all the resources they desire: 'With little employment opportunities on their own territory, being economically unimportant, and having poor-quality land that now made agriculture nearly impossible, the Bantustans acted as reservoirs of cheap labour for the South African economy. Some of them were simply oversized dormitories for migrant African labourers whose stay in South African industrial centres was dependent upon their remaining in employment', Datta, 'Bantustans', p. 153.

so Snorri, Gylfaginning, p. 9; Codex Regius $2^{r}$; Codex Trajectinus $3^{r}$. 
to those who are foreign to it and do not have their native land there. He who is named Surtr sits at the land's end to defend it. He carries a flaming sword, and at the end of the world he will go and attack and defeat all the gods and burn all the world with fire.)

It is reasonable to assume that Surtr is a giant, although Snorri does not explicitly identify him as such: he is opposed to the gods, and later he will ride with the Muspellssynir (the coalition of giants who will attack the gods at Ragnarǫk/Ragnarøkr). He is therefore uncontroversially counted as a giant by both Lindow and Simek..$^{51}$ Snorri does not make clear who exactly counts Muspell as their ó ðal (native land), but one presumes that, like Surtr, they are other giants. Just as the giants are condemned to live in searing heat in Muspell, they seem to be relegated to the freezing cold in the land known as Niflheimr. Ymir appears to have lived in Niflheimr before the creation of the other worlds (Muspell, Miðgarðr, etc.). Snorri describes a spring in the country's interior which has an apparently Giantish name, Hvergelmir, lending further support to the ongoing presence of giants in the region. (The -gelmir element is common in the language of the giants, both in the Poetic Edda and Snorra Edda, e.g. Aurgelmir, the Giantish name for Ymir, Bergelmir, the Noah-like giant who survived the great flood, Prúdgelmir, his father according to stanza 29 in Vafprúdnismál).$^{52}$ Indeed, the type of giant known as a hrimpurs (Ice Giant) is arguably best explained as hailing from frozen Niflheimr. The dispersal of the giants across several, isolated reservations also explains why Snorri does not speak of a singular Jotunheimr 'Giantland', but instead prefers the plural Jetunheimar 'the Giantlands'. As Lindow points out, this accords with Scandinavian traditions that certain areas of mountain and forest - places which humans did not find hospitable - were home to giants and trolls. ${ }^{53}$

The Æsir's walls, then, are more than reactive defences. They are both symbols and means of an enduring marginalization of the giants. A reader might find it frustrating that although Snorri is the only author to supply the detail that Óðinn and his brothers killed Ymir he does not tell us what precise justification Óðinn had in mind. Óðinn expresses the view that Ymir wa illr 'evil', but does not substantiate this opinion with examples of the giant's wrongdoing. Conceivably, this omission is deliberate: Snorri is configuring Óðinn as an unreliable narrator, who does not provide a sound moral reason for his act of violence because there was no sound moral reason. Perhaps the real reason that the proto-Æsir felt entitled to take the world from the giants, rather than attempting to found a bicultural Æsir-giant society, was simply that they could. The history of colonialism at many times and places has been

51 Lindow, Norse Mythology, pp. 282-83; Simek, Dictionary, pp. 303-04.

$\$ 2$ Poetic Edda, ed. by Neckel and Kuhn, p. 59 .

53 Lindow, Norse Mythology, p. 206 one of a civilization taking land and resources from another, and inventing a pretext afterwards, e.g. the invention of the 'manifest destiny' principle long after the first conquests of indigenous Americans, or the pinnacle of European scientific racism in the nineteenth century coming after the establishment of paternalistic regimes in Africa and Australasia. As Homi Bhabha notes: 'The objective of colonial discourse is to construe the colonized as a population of degenerate types on the basis of racial origin, in order to justify conquest and to establish systems of administration and instruction.'s Action precedes justification.

This history of violence and conquest between the Æsir and the giants means that the walls around Ásgarðr and Miðgarðr are most fully understood not as ideologically neutral defensive measures (indeed, a basic premise of this chapter is that there is really no such thing as ideological neutrality). Rather, the defences of the Æsir are more like the castles built by conquerors in the Middle Ages, during Snorri's own days. They are not just for keeping out threats, but also for reminding locals of the new order, and for legitimizing ownership over land that has essentially been claimed through the principle that 'might makes right'. It seems fair at this point to conclude that Æsirism features a strain of something like what we would today recognize as colonialism. ${ }^{55}$

\section{Conclusion}

In the opening to this study, the condition was made clear that comparison between Æsirism and other ideologies could only ever offer analogies: in such-and-such a regard, Æsirism is like such-and-such an ideology. It is not a forerunner thereof. That is to say, Æsirism is not anarchism before anarchism, or fascism before fascism, etc. The prospect of comparing ideologies past and present - or, fictional and historical - poses the question of how an ideology exists. It would be convenient if it could be said that an ideology did not really exist until it had been proposed in a printed manifesto. However, this is not a tenable suggestion, as the manifesto is essentially an eighteenth-century genre, and it is self-evident that ideologies have governed human behaviour for a great deal longer. ${ }^{56} \mathrm{Here}$, the etymology of manifesto, 'I make clear', is revealing: a manifesto only makes apparent a thing which previously existed unnamed.

54 Bhabha, "The Other Question', p. 23.

S5 Further colonial dynamics, pertaining to the 'race' and gender of the giants, are studied in detail by Cole, 'Æsirist Ideology', pp. 69-77. See also: Clunies Ross, Prolonged Echoes, I, 48-50, 56-84.

56 Myth itself can serve as ideological articulation avant la lettre, e.g. Lincoln, Theorizing Myth esp. pp. 19, 29. A related but distinct question is whether there was ever a 'prelapsarian' time when humans did not produce ideology. Runciman has argued that in the earliest part of the palaeolithic 'for many tens of thousands of years, bands of anatomically modern human beings no longer dominated by alpha males were able to solve the problem of order without 
It is sensible to believe that ideologies do not require manifestos or other texts in order to exist. If ideology is an assemblage of beliefs which governs the behaviours and inclinations of individuals, the key thing is that ideologies reside in the mind, rather than on the page. Texts may serve as vessels for the preservation and communication of ideology, but they are not themselves the seat of ideologically conditioned thought. When, in medieval Europe, an illiterate Christian townsman attacked his Jewish neighbour, the crucial psychological mechanism was that the ideology of anti-Semitism had been internalized in his mind. The existence of anti-Semitism is not affected by how he became inculcated with a hatred of Jews: through preaching texts read aloud, caricatures painted on a church wall, or gruesome miracle tales spread by word of mouth. Is it true, then, to say that an ideology exists so long as people believe in it? There are ideologies which are extensively documented (even if none of the texts which record their tenets are manifestos in the modern sense), but which are no longer practised. Feudalism has not ceased to exist - thinkers continue to explore its consequences and its ideological intricacies today just as one could have done in the thirteenth century. It has only ceased to shape the world. ${ }^{57}$

It seems, then, that ideologies do not require texts, and they do not require faithful, active believers. They must therefore be considered immateria phenomena. The implication is therefore that they are timeless. In some difficult metaphysical sense, anarchism 'existed' before the first self-declared anarchists of the eighteenth century. Norman Cohn was therefore quite right to describe the Taborites and similar heretical movements of the fifteenth-century as 'anarcho-communist'.58 If we could travel through time and interview a Taborite, he/she would not even understand the word 'anarcho-communism'. But their beliefs, so far as they are preserved in the sources, would to a great degree be harmonious with those of today's anarcho-communists. We would obscure the true nature of the ideology in question if we were to insist on a separate designation.

On the other hand, identifying an '-ism' is a task which ideally would require perfect ideological neutrality on the part of the identifier. The optimal situation would be for a scholar to rid him/herself completely of their own ideological commitments, and turn their mind into a sort of 'ideology detector'; hovering over a particular text, we would then be able to recognize the ideological message it seeks to convey with such clarity that it would be

any awareness of the possibility of, let alone the need for, formal institutional roles to which there attached impersonal economic, ideological, or political inducements and sanctions ('Stone Age Sociology', p. 138). I am sceptical that we have ever been anything other than homo ideologis, but 1 have ne argument is certainly

7 Note that some commentators worry about the re-emergence of a 'techno-feudalism', though this is beyond the scope of the present chapter, e.g.: Seabrook, Cut Out, p. 240. 58 Cohn, Pursuit of the Millcnium, p. 215. as though we could read the mind of the author. However, this is obviously not possible. Any commentary on the ideology of another person is always conditioned by the commentator's ideological concerns. I do not mean only that it is extremely challenging to refrain from implicit value judgements (for example, it is challenging to describe fascism in terms that are anything other than excoriating, even while we strive for academic objectivity). Rather, even our categories for examining a foreign ideology inevitably betray our own commitments. I have asked how Æsirism understands gender, government, and race. These are all ideological concerns one might expect from someone living in north-western Europe during the early twenty-first-century. People from other times and places might well find wholly different categories to be their obvious starting point. No set of categories is necessarily superior to any other — they are all just symptoms of the impossibility of ideological translucence.

The same dilemma is observable in Snorra Edda. The sword-juggling jester at the opening of Gylfaginning compares Óðinn to a king in order to depict a foreign ideology in terms Gylfi can understand. It is not a wholly misleading exercise. Óðinn is clearly a leader of sorts, de facto if not de jure. But it would never occur to Óðinn to call himself a king. The same is true of my comparisons with anarchism. The Æsir's kingless society may be de facto 'anarchist' in our eyes, but obviously neither Óðinn nor Snorri would have used that term. Thus, we turn again to de Vries and Waddell: Is a study like mine no nobler than the undertakings of the Nazi or Victorian philologists, who so brazenly projected their own world-view onto the past? One might protest that where they found a glorious Germanic past, ripe for cross-fertilization with nationalistic expansionism, patriarchal normativity, and anti-Semitism, I have found lessons for our own time on colonialism (and, elsewhere, desire, racism, and the twilight of capitalism) ${ }^{59}$ I would therefore have corrupted Old Norse myth no less than they did. To draw the aforementioned equivalence would be a relativist interpretation of the situation, and I would not propose to prove somebody wrong who subscribed to that approach.

But there is also a more generous, absolutist interpretation to be had. Let us take a pinch of relativism for a moment, and assume that a person of a given ideological bent (for example, fascism) will, given enough time and creativity, be able to warp any body of myth to meet their needs. Even from this relativist starting point, I would not suppose that all bodies of myth are equally susceptible targets. An absolutist might protest that in this regard there are manifest differences between, for example, Christianity and pre-Christian Scandinavian paganism. The Christian Bible contains many moments where secular power is explicitly rejected, and equality between genders and races is strenuously recommended, e.g. Galatians 3.28 'There is neither Jew nor Greek, there is neither bond nor free, there is neither male nor female: for ye are all

59 Cole, 'Æsirist Ideology'. 
one in Christ Jesus' (see also Joel 2. 29, I Corinthians 12. 13, Colossians 3.11, Acts 2. 32-47, etc.). This presents a serious stumbling block for a fascist who would commandeer the Christian mythos. True, the persistent fascist will overcome it eventually (as shown by the historical example of the Deutsche Christen, and other Christian groups who embrace far-right politics today). Contrary examples from elsewhere in the Christian corpus will be found, or exegetical apparatus will be constructed which explains away the ideologically uncomfortable parts of the text. ${ }^{60}$

However, co-opting the Æsir requires no such effort, because so far as we can see in the surviving mythological sources there are no statements which promote egalitarianism or intercultural understanding to the exten that, for example, Acts or Galatians do. I do not mean to say that the fascist philologists really had some sort of glimmer of insight into Old Norse myth. There is also much that a fascist might desire from Snorra Edda which they will not find in its pages. For example, Snorri has virtually nothing in the way of concepts that might be interpreted as whiteness, heteronormativity, or the nation state. But I would like to dislodge the implication that Snorri's myths were ideologically neutral before the grubby fingers of the far-right began to caress them. I am sceptical of moral relativism when comparing different ideologies. Some are peaceable and/or well-intended. Even if thei attempted implementations have resulted in unimaginable cruelty, in the abstract realm where ideologies properly exist, they recommend kindness. Other ideologies are bellicose and exploitative. They are kind neither in theory nor in practice. My contention has been that Æsirism belongs more to the latter sort than the former

\section{Works Cited}

\section{Primary Sources}

Gylfaginning = Snorri Sturluson, Edda. Prologue and Gylfaginning, ed. by Anthony Faulkes (London: Viking Society for Northern Research, 1988)

Hesiod, Theogony. Works and Days. Testimonia, ed. and trans. by Glenn W. Most,

Loeb Classical Library 57 (Cambridge, MA: Harvard University Press, 2006) Homer, Iliad. Books 13-24, ed. and trans. by C. P. Goold, Loeb Classical Library 171

(Cambridge, MA: Harvard University Press, 1991)

60 A similar process has occurred with Christianity in America, where although a kernel of compassionate Christians remains, many of those who identify as 'Christian' presently support a regime which is extremely hostile to the ideological commitments of the New Testament. My point is that a protracted history of ideological wrangling was required to reach this point - hundreds of years of dubious exegesis were required to make Christian amenable to slavery, capitalism, etc. (see Salley and Behm, Your God, pp. 15-28; Block, The Future of an Illusion, pp. 94-96).
Old Norwegian Homily Book = Gamal norsk homiliebok. Cod. AM 619 4to, ed. by Gustav Indrebø (Oslo: Universitetsforlaget, 1966)

Poetic Edda $=$ Edda. Die Lieder des Codex Regius nebst verwandten Denkmälern, ed. by Gustav Neckel and rev. by Hans Kuhn (Heidelberg: Winter, 1983)

Skáldskaparmál = Snorri Sturluson, Edda. Skáldskaparmál, vol. I, ed. by Anthony Faulkes (London: Viking Society for Northern Research, 1998)

Snorri Sturluson, Heimskringla, vol. I, ed. by Bjarni Aðalbjarnarson, Íslensk Fornrit 26 (Reykjavík: Hið íslenzka fornritafélag, 1941)

Sturla Pórðarson, Sturlunga saga efter membranen Króksfjarðarbók udfyldt efter Reykfjarðarbók, vol. I, ed. by Kristian Kålund (Copenhagen: Gyldendalske boghandel, 1906-1911)

Virgil, Eclogues. Georgics. Aeneid I-VI, vol. I, ed. by C. P. Goold, trans. by H. Rushton Fairclough, Loeb Classical Library 63 (Cambridge, MA: Harvard University Press, 1999)

Ynglinga saga = Snorri Sturluson, Heimskringla, vol. I, ed. by Bjarni Aðalbjarnarson, Íslensk Fornrit 26 (Reykjavík: Hið íslenzka fornritafélag, 1941)

\section{Secondary Studies}

AFAQWorking Group, 'Is Medieval Iceland an Example of "Anarcho"-Capitalism Working in Practice?', An Anarchist FAQ (2017), n. p. <http://www.infoshop. org/an-anarchist-faq-f-9-is-medieval-iceland-an-example-of-anarchocapitalism-working-in-practice/> [accessed 31 January 2020]

Bagge, Sverre, Society and Politics in Snorri Sturluson's Heimskringla (Berkeley: University of California Press, 1991)

Bhabha, Homi K., 'The Other Question ..., Screen, 24, 6 (1983), 18-36

Block, Fred L., Capitalism: The Future of an Illusion (Berkeley: University of California Press, 2018)

Clunies Ross, Margaret, A History of Old Norse Poetry and Poetics (Cambridge: D. S. Brewer, 2005)

-, Prolonged Echoes. Old Norse Myths in Medieval Northern Society. Volume 1: The Myths (Odense: Odense University Press, 1994)

-, 'Royal Ideology in Early Scandinavia: A Theory Versus the Texts', Journal of English and Germanic Philology, 113/1 (2014), 18-33

Cohn, Norman, The Pursuit of the Millenium. Revolutionary Millenarians and Mystical Anarchists of the Middle Ages (Oxford: Oxford University Press, 1970)

Cole, Richard, 'In Pursuit of an Æsirist Ideology', Viking and Medieval Scandinavia, 15 (2020), 65-101

-, 'Philology and Desire in Old Norse, between Stone and a Hard Place', Journal of English and Germanic Philology, 177/4 (2018), 505-25

Datta, Kusum, 'Bantustans', in Encyclopedia of the Developing World, vol. I, ed. by Thomas M. Leonard (New York: Routledge, 2006), pp. 152-54

Ellis Davidson, H. R., Gods and Myths of Northern Europe (London: Penguin, 1964) 
Faulkes, Anthony, 'Introduction to Snorri Sturluson', in Edda. Prologue and Gylfaginning, ed. by Anthony Faulkes (London: Viking Society for Northern Research, 1988), pp. xi-xxxiv

Fisher, Jay, The 'Annals' of Quintus Ennius and the Italic Tradition (Baltimore: Johns Hopkins University Press, 2014)

Friedman, David, Law's Order. What Economics Has to Do with Law and Why it Matters (Princeton: Princeton University Press, 2000)

-, Machinery of Freedom. Guide to a Radical Capitalism (Chicago: Open Court, 1989)

-, 'Private Creation and Enforcement of Law: A Historical Case', Journal of Legal Studies, 8/2 (1979), 399-416

Heimir Pálsson, 'Introduction to Snorri Sturluson', The Uppsala Edda. DG 11 4to, ed. by Heimir Pálsson, trans. by Anthony Faulkes (London: Viking Society for Northern Research, 2012), pp. xi-cxxviii

Hofstee, Willem, 'The Essence of Concrete Individuality. Gerardus van der Leeuw, Jan de Vries, and National Socialism', in The Study of Religion Under the Impact of Fascism, ed. by Horst Junginger (Leiden: Brill, 2008), pp. 543-52

Jonassen, Christen T., 'Some Historical and Theoretical Bases of Racism in Northwestern Europe', Social Forces, 30/2 (1951), 155-61

Junginger, Horst, 'Introduction', in The Study of Religion Under the Impact of Fascism, ed. by Horst Junginger (Leiden: Brill, 2008), pp. 1-106

Kropotkin, Peter, Mutual Aid. A Factor of Evolution (London: Heinemann, 1914) Lincoln, Bruce, 'Rewriting the German War God: Georges Dumézil, Politics and Scholarship in the Late 1930s', History of Religions, 37/3 (1998), 187-208

-, Theorizing Myth: Narrative, Ideology, and Scholarship (Chicago: University of Chicago Press, 1999)

Lindow, John, Norse Mythology: A Guide to the Gods, Heroes, Rituals, and Beliefs (Oxford: Oxford University Press, 2001)

Pencak, William, The Conflict of Law and Justice in the Icelandic Sagas (Amsterdam: Rodopi, 1995)

Runciman, Walter Garrison, 'Stone Age Sociology', The Journal of the Royal Anthropological Institute, 11/1 (2005), 129-42

Salley, Columbus, and Ronald Behm, Your God Is Too White (Berkhamsted: Lion Publishing, 1973)

Seabrook, Jeremy, Cut Out: Living Without Welfare (London: Pluto Press, 2016)

Simek, Rudolf, Dictionary of Northern Mythology, trans. Angela Hall (Cambridge: D. S. Brewer, 1993

Turville-Petre, E. O. G., Myth and Religion of the North. The Religion of Ancient Scandinavia (London: Weidenfeld and Nicolson, 1964)

Waddell, Laurence, The British Edda (London: Chapman \& Hall, 1930)

Wanner, Kevin J., Snorri Sturluson and the 'Edda'. The Conversion of Cultural Capital in Medieval Scandinavia (Toronto: University of Toronto Press, 2008)

Wax, Rosalie, and Murray Wax, 'The Vikings and the Rise of Capitalism', The American Journal of Sociology, 61/1 (1955), 1-10

Žižek, Slavoj, First as Tragedy, then as Farce (London: Verso, 2009)

—, The Sublime Object of Ideology (London: Verso, 2008)

\section{Scholarly Uses}

